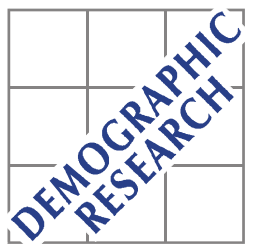

Demographic Research a free, expedited, online journal of peer-reviewed research and commentary in the population sciences published by the Max Planck Institute for Demographic Research Konrad-Zuse Str. 1, D-18057 Rostock · GERMANY www.demographic-research.org

DEMOGRAPHIC RESEARCH

VOLUME 20, ARTICLE 9, PAGES 169-194

PUBLISHED 20 FEBRUARY 2009

http://www.demographic-research.org/Volumes/Vol20/9/

DOI: $10.4054 /$ DemRes.2009.20.9

Research Article

\title{
Is Latin America starting to retreat from early and universal childbearing?
}

\section{Luis Rosero-Bixby}

Teresa Castro-Martín

Teresa Martín-García

(C) 2009 Rosero-Bixby, Castro-Martín \& Martín-Garcia

This open-access work is published under the terms of the Creative Commons Attribution NonCommercial License 2.0 Germany, which permits use, reproduction \& distribution in any medium for non-commercial purposes, provided the original author(s) and source are given credit.

See http:// creativecommons.org/licenses/by-nc/2.0/de/ 


\section{Table of Contents}

1 Introduction $\quad 170$

1.1 The Latin American demographic context 171

2 Data and methods $\quad 173$

3 Results 174

$\begin{array}{lll}4 & \text { Discussion } & 187\end{array}$

$5 \quad$ Acknowledgements 189

$\begin{array}{ll}\text { References } & 190\end{array}$ 


\title{
Is Latin America starting to retreat from early and universal childbearing?
}

\author{
Luis Rosero-Bixby ${ }^{1}$ \\ Teresa Castro-Martín ${ }^{2}$ \\ Teresa Martín-García ${ }^{3}$
}

\begin{abstract}
The 2000 censuses show that the proportion of women below age 30 who are mothers has dropped substantially in most Latin America countries, suggesting that the social imperative of early motherhood, which has long prevailed in the region, is weakening. Surveys conducted in 14 Latin American countries in 2006 also show a strong link between childlessness and higher education across several cohorts. We discuss whether the recent increase in childlessness among young women reflects a shift towards later childbearing, a novel trend in the Latin American context, and also whether it may signal an emerging retreat from universal childbearing in the region.
\end{abstract}

\footnotetext{
${ }^{1}$ Centro Centroamericano de Población, Universidad de Costa Rica (UCR). San Jose 2060. Costa Rica. Fax: (506)2207-4809. E-mail: lrosero@ccp.ucr.ac.cr.

${ }^{2}$ Centro de Ciencias Humanas y Sociales, CSIC, Madrid, Spain. E-mail: teresa.castro@cchs.csic.es.

${ }^{3}$ Centro de Ciencias Humanas y Sociales, CSIC, Madrid, Spain. E-mail: teresa.martin@cchs.csic.es.
} 


\section{Introduction}

Latin America is quickly approaching fertility replacement levels. Although the pace of fertility decline has been uneven across countries ${ }^{4}$ (Guzmán et al. 1996), recent data show that more than half of the 20 Latin American countries had total fertility rates (TFR) close to or below replacement levels by 2005 (Population Reference Bureau 2007). This group includes the four largest countries in the region: Brazil, Mexico, Colombia, and Argentina; as well as five countries with populations that have already crossed the replacement threshold (with TFR lower than 2.1): Uruguay, Chile, Costa Rica, Puerto Rico, and Cuba. Fertility patterns and trends at these low levels may be strongly determined by women's behavior in entering maternity; that is, by rates of first births and age schedules. If motherhood continues to be almost universal and early, it seems unlikely that the region will eventually reach the very low fertility levels observed in several European and East Asian countries (Kohler, Billari, and Ortega 2002). Conversely, if larger proportions of Latin Americans opt to have their first child at older ages, or to remain childless, the region could reach very low fertility levels sooner rather than later.

Until now, a distinctive feature of the process of fertility decline in Latin America was that it took place without major changes in the onset of family formation, as indicated by fairly stable rates and ages at first union and first birth (Rosero-Bixby 1996, 2004, Mensch, Singh, and Casterline 2005). It seems, however, that Latin America has entered into a new stage of the fertility decline process in recent years. The proportion of women under 30 who have made the transition to motherhood has dropped significantly in most Latin American countries in the past decade. In Costa Rica, for example, the estimated proportion of women who would be mothers by age 30 , according to the rates of the study year, fell from above $80 \%$ to about $65 \%$ from 1995 to 2005. Drawing on the European experience, this article discusses whether this reduction in rates of motherhood among young adults reflects a novel shift in the starting age of childbearing, an emerging retreat from universal childbearing, or a combination of both.

The study of childlessness among younger groups adds a complementary perspective to earlier research. Previous studies on childlessness in developing countries have been traditionally confined to the end of the reproductive span; i.e., among women in the oldest reproductive age groups, usually over age 40 . Based on the

\footnotetext{
${ }^{4}$ For example, Mexico and Brazil have experienced a rapid and sharp fertility transition over the last thirty years; Chile, Uruguay and Argentina already displayed a relatively low level of fertility in the 1970s and the reduction in fertility rates has been moderate thereafter. In Guatemala, Bolivia, Honduras, Paraguay and Nicaragua, fertility rates remain relatively high at present (United Nations 2007).
} 
assumption that the desire for children is practically universal in developing countries, childlessness has been typically attributed to involuntary infecundity. The comparison of data from the World Fertility Surveys and the Demographic and Health Surveys reveals that permanent childlessness has diminished in Latin America since the 1970s (United Nations 2004). However, the proportion of childless women aged 25 to 49 has recently increased in several countries of the region (Rutstein and Shah 2004), suggesting that childbearing is intentionally postponed (or foregone) by an increasing proportion of young adults.

This article documents the levels and trends of childlessness among young adult women in 16 Latin American countries between 1970 and 2000 with data from four waves of population censuses. It also identifies factors that are associated with childlessness using individual-level data from a 2006 series of surveys conducted in 14 Latin American countries. The article focuses primarily on cohort fertility, given that it has been shown that period indicators of fertility may be distorted by what Ryder called “demographic translation” effects (Ryder 1964), also known as tempo effects in more recent literature (Bongaarts and Feeney 1998). For example, while period total fertility rates are as low as 1.2 and 1.3 in several European countries, the lowest estimates of complete cohort fertility in those countries are in the order of 1.5 to 1.7 births among cohorts born circa 1970 (Sardon 2006). The persistent postponement of births biases downwards the estimates of period fertility rates because there can be a recuperation of fertility at older ages. However, it is well documented that, in general, "later means fewer" children (Rindfuss and Bumpass 1976), or even no children.

\subsection{The Latin American demographic context}

Considering the far-reaching economic, social, and political transformations that Latin America experienced in the second half of the $20^{\text {th }}$ century, it remains somewhat of a puzzle that demographic indicators of family formation, such as age at first union and age at first birth, have shown, until very recently, so little change (Heaton, Forste, and Otterstrom 2002). During these past decades, major structural transformations affected the organization of society, particularly the expansion of mass education, rapid urbanization, and internal rural to urban migration, as well as the transition to democratic governments in the political domain. Women's education and employment levels, which are known to influence family formation, also increased rapidly during this period. For example, the participation of women in the labor force increased from around $20 \%$ in the 1950 s to over $50 \%$ in the 1990 s, albeit with large differences according to country, area of residence, age and educational level (ECLAC 2007). The increase was particularly sharp after the debt crisis that affected the region in the 1980s, 
and the subsequent economic restructuring of the 1990s. The deterioration of the economy, increasing unemployment, and precarious attachment to the labour force rendered the traditional male breadwinner family model unsustainable (Jelin and DíazMuñoz 2003). Despite these trends, early life course transitions, such as the transition to first union and motherhood, changed remarkably little (Fussell 2005).

Fertility in the Latin American region as a whole declined from 5.9 births per woman in 1950-1955 to 2.5 in 2000-2005 (United Nations 2007). However, as mentioned above, this rapid and sustained process of fertility decline was not accompanied by a gradual delay in the onset of childbearing, as has been the norm in European countries (Sobotka 2004). In the early 1990s, relatively low fertility coexisted with traditional patterns of family formation -i.e., early nuptiality and young motherhood- in many Latin American countries. Fussell and Palloni (2004) argue that the explanation for this distinct Latin American pattern ${ }^{5}$ lies in the strong cultural emphasis on family ties. According to these authors, the value placed on family networks, which represent the primary safety net guarding against economic and social instability, would explain the persistence of nearly universal and early family formation, despite major changes in the economic, political, and social spheres.

Traditional patterns are, however, not immutable, and it is reasonable to expect that behavior regarding motherhood will eventually change in the face of modernizing forces, such as women's education and salaried work, particularly when the average desired family size has declined to about two children in most Latin American countries (Westoff and Bankole 2002). Younger cohorts, particularly if they have had access to higher education, are likely to reach adulthood with different aspirations regarding marriage and family, work life, economic self-sufficiency, and lifestyle than their mothers and grandmothers, as has occurred in Western societies (Crimmins, Easterlin and Saito 1991). Delaying childbearing could be a suitable strategy that allows them to pursue higher education, establish themselves in the labour market, build their couple relationship before child-rearing, and also to deal with unstable life conditions or uncertainty in the economic context (Adsera and Menéndez 2006).

\footnotetext{
${ }^{5}$ Fertility patterns in Eastern Europe also reflect the atypical coexistence of very low fertility and early transition to childbearing, but an upward trend towards later motherhood has recently started (Council of Europe 2005).
} 


\section{Data and methods}

Drawing on the classic study of the decline of fertility in Europe that decomposed childbearing into marriage and marital fertility indexes (Coale and Watkins 1986), the starting point in this article is the following identity that decomposes total fertility $\mathrm{F}$ into two different processes:

(1) the proportion of women who became mothers, or motherhood rate $M$, and

(2) the fertility of mothers, or $G$ rate, which is simply the additional number of children that mothers have:

$$
F=M(G+1)
$$

Our trend analysis is based on cohort estimates of $F$ and $M$ from the four waves of censuses conducted in 16 Latin American countries since 1970. The $G$ rate is derived from the above identity. We focus on $M$ at ages 25-29, which the data shows represents $87 \%$ (5\% SD) of complete $M$ in Latin America (cohorts in these data reach complete $M$ by age 40 ). And we focus on $G$ in the age bracket 30-34, which includes $80 \%$ (5\% SD) of complete $G$ in each cohort. In some analyses, we estimate complete $M$ and $G$ for cohorts born in the 1970s from the quasi-complete figures at ages 25-29 and 30-34, respectively, using relations derived from the data. The census data were taken from several sources, including the UN Demographic Yearbook, as well as online census data on the web from the IPUMS project (Minnesota Population Center 2008), the University of Costa Rica (CCP 2008), and the census offices in Colombia, Brazil, Chile, Mexico, Nicaragua, and Honduras.

This decomposition of fertility in $M$ and $G$ was used in an earlier study of the prospects of below-replacement fertility in 15 metropolitan areas of Latin America (Rosero-Bixby 2004). For comparison purposes, we also use the most recent estimates of cohorts $M$ and $G$ for 22 European countries, which correspond to the cohorts born circa 1970. The lowest estimates of cohort total fertility in this group of European countries are in the order of 1.5 to 1.7 births. The estimates come from the European Demographic Observatory (Sardon 2006), and the countries are: Austria, Bulgaria, Croatia, Czech Republic, Denmark, England and Wales, Finland, Greece, Hungary, Ireland, Latvia, Netherlands, Norway, Poland, Portugal, Romania, Russia, Serbia, Slovakia, Slovenia, Spain, and Sweden (countries with no available estimates for 1970s cohorts were not considered). In addition, we use published cohort estimates of completed- $M$ and $M$ at age 27 for five cohorts in 23 developed countries (Frejka and Sardon 2007) to identify an intra-cohort relationship between these two figures, which we then use to estimate a scenario of completed- $M$ in the 1970s birth cohorts in Latin America. 
In order to examine in more detail recent trends in motherhood rates, we use vital statistics data on first births in Chile and Costa Rica in the period 1980-2006. These are the only countries in the region with accessible and reliable series of numbers of births by birth order. We estimate the time series of period- $M$ at age 30 (sum of age specific first birth rates), as well as the period median age at motherhood (i.e., when $50 \%$ of women reach motherhood) in these two countries.

In complementary analyses of factors associated with childlessness, we use microdata from surveys conducted in 14 Latin American countries in 2006 as part of the Latin American Public Opinion Project (LAPOP 2008) of the "Americas Barometer" of the Vanderbilt University ${ }^{6}$. These are nationally representative surveys of adult women and men aged 18 and over, with a sample size of around 1,500 in each country. The questions mainly focus on political themes, such as voting participation, tolerance, and support of democracy, and citizens' rights. However, by including questions on the number of children and socioeconomic status, these surveys offer a rare opportunity for comparing the co-factors of the prevalence of childlessness in several cohorts and across 14 Latin American countries. Using logistic regression, this article estimates cross-sectional effects on the probability of being childless, contrasting results across three age or cohort groups (women aged 20-29, 30-39, and 40-49 in 2006). The covariates included in the model are: urban residence, educational level, occupation, household wealth (a zero to one scale built by counting up to 11 household assets), religion and religiosity, trust in neighbors (an indicator of social capital measured with a zero to one scale), satisfaction with life (an indicator of self- perceived wellbeing measured with a zero to one scale), and sources of news, since some authors postulate an important role of television (telenovelas, in particular) for the diffusion of modern lifestyles and family values in Latin America (Potter, Schmertmann, and Cavenaghi 2002). Age and marital status are included as controls, and interactions between age and several covariates are also explored.

\section{Results}

Figure 1 (Part B) shows the remarkable drop in the $G$ rate or fertility of mothers from cohorts aged 30 to 34 in the 1970 wave of censuses (born around 1940), to analogous cohorts in the 2000 censuses born around 1970 . At these ages, about $80 \%$ of the final $G$ fertility of the cohort is usually completed in Latin America. The oldest cohorts were at

\footnotetext{
${ }^{6}$ The countries are Mexico, Guatemala, El Salvador, Honduras, Nicaragua, Costa Rica, Panama, Colombia, Ecuador, Bolivia, Peru, Paraguay, Chile, and the Dominican Republic.
} 
Figure 1: $\quad$ M proportion and $G$ rate in Latin American countries over four census waves
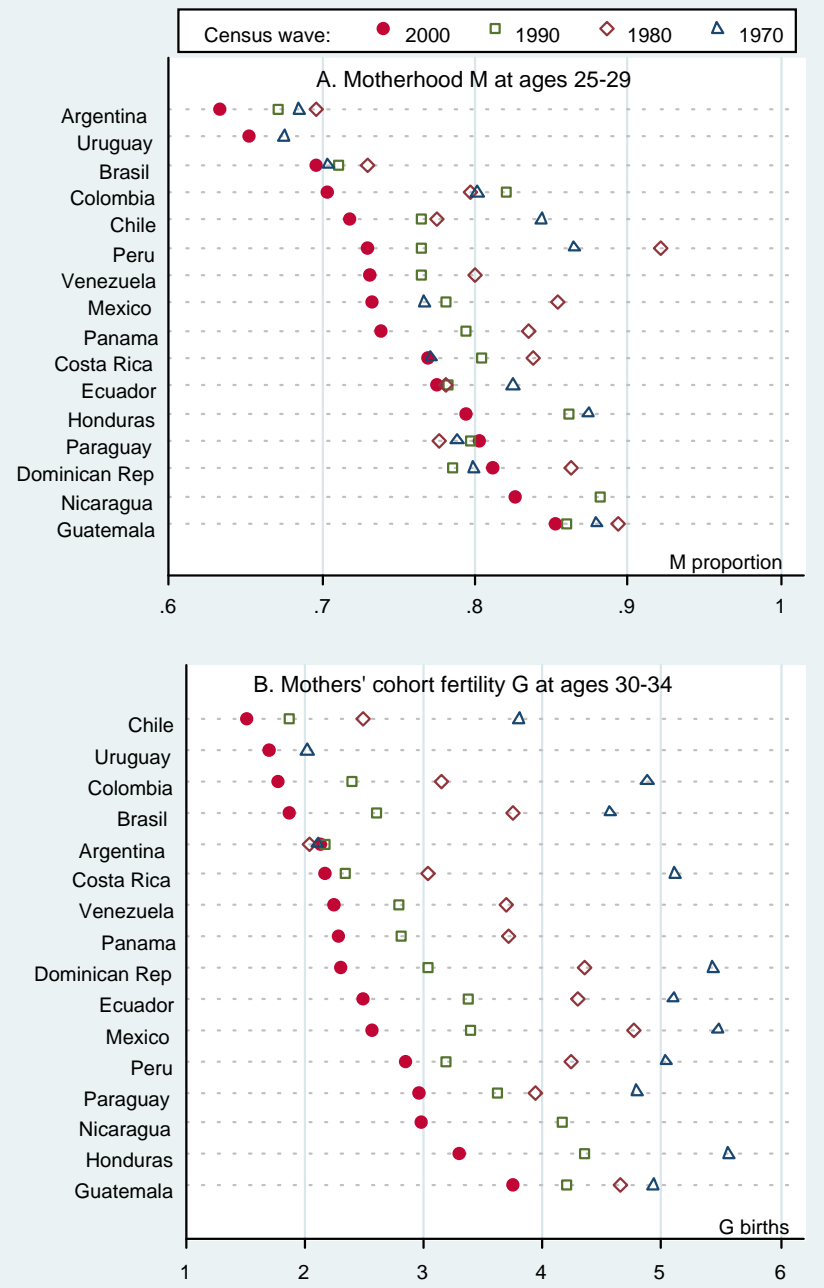
their peak reproductive ages in the 1960s, and the youngest cohorts reached these ages in the 1990s. Most countries went from a $G$ rate of four or five children to a rate of around two children in these 30 years. The exceptions are, on the one hand, Argentina and Uruguay, which already had $G$ rates of about two births from 1970 onwards; and, on the other hand, Honduras and Guatemala, the only countries with $G$ rates higher than three births in 2000.

Trends are different in the proportion $M$ of motherhood in the 25-29 age bracket (Figure 1, Part A), when close to $90 \%$ of the final cohort- $M$ is usually completed in Latin America. First, there is no clear pattern of change from 1970 to 1990. In some countries, such as Chile and Peru, there are declines of about 10 percentage points in $M$, whereas in most countries, including the four regional giants, Brazil, Mexico, Argentina and Colombia, the $M$ change from 1970 to 1990 is only about two percentage points in any direction. In contrast, between the last two waves of censuses, from 1990 to 2000, there is a clear drop in $M$ in almost all countries. With the exceptions of the Dominican Republic and Paraguay, the $M$ proportion reached its historic low in the 2000 wave of censuses.

Period indicators of $M$ illustrate these trends more sharply. Figure 2 shows the evolution over time in the period-M at age 30 and the period median age of entry into motherhood in Chile and Costa Rica, the only Latin American countries with readily available series that are sufficiently long. Three points emerge from Figure 2:

(1) there are no clear trends before 1990;

(2) starting in about 1990, there is a clear increase of almost three years in the median age at first birth over a period of about 10 years; and

(3) there is a sharp drop of almost 20 percentage points in $M$ in the decade of 1990.

The $M$ proportion of mothers is below $65 \%$ at the end of the series. Considering that, in the past, no more than $10 \%$ of women entered motherhood after age 30 , this might imply that as many as one in four women could end her reproductive life childless. This is, however, a naïve interpretation of a period- $M$ that may be down-biased by the shift in tempo of first birth. It is plausible that women will enter motherhood after age 30 in significantly higher proportions than in the past if recent changes are driven mostly by a temporal postponement of the first birth.

Returning to the census-based cohort estimates of $G$ and $M$, in order to include younger cohorts (born in the 1970s) in trend analyses, we completed the final 10 years of the $G$ rate for cohorts born around 1970 (observed until about age 32), as well as the 
Figure 2: Trend in motherhood proportion at age 30 and median age at motherhood. Period rates in Costa Rica and Chile

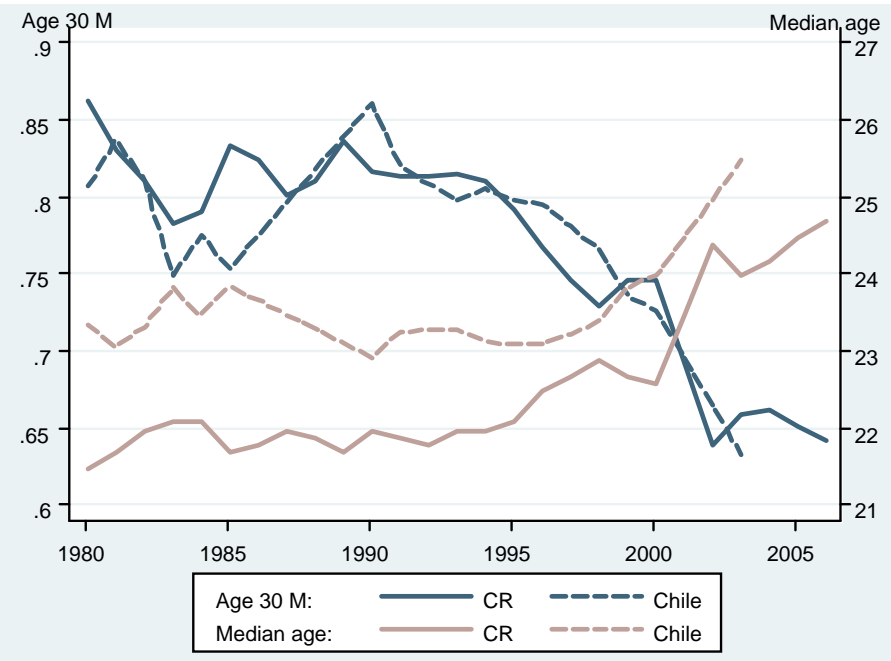

final 10 years of the $M$ proportion for women born around 1975 (observed until about age 27 in the 2000 wave of censuses). To complete the cohort $G$ rate, we estimated a simple regression model with $G$ in the same cohort 10 years earlier as the predictor variable, using fixed effects estimates in the panel of 16 Latin American countries. The resulting equation for a cohort $c$ was (standard errors in parentheses):

$$
\begin{array}{rlr}
G_{40-44}^{c} & =0.335+1.145 \times G_{30-34}^{c} \\
& (0.20)(0.07) & \mathrm{R}^{2}=0.92
\end{array}
$$

To complete $M$, we followed the same procedure as Frejka and Sardon (2007), and assumed that the rate in the coming 10 years would be the same as in the previous 10year period in the same country and ages. However, this assumption corresponds to a traditional scenario in which very low proportions of women commence childbearing in their thirties, which had been the pattern until recently. It is quite plausible that women in younger cohorts who did not start childbearing in their twenties will do so in their thirties, resulting in substantially higher rates of late transition to motherhood similar to those seen in Europe. We thus assumed, as an alternative scenario, that young Latin American cohorts will display the same behavior as their European counterparts. Based 
on this assumption, we completed the $\mathrm{M}$ proportion with a relationship derived from the panel data for 23 countries and five cohorts in the Frejka and Sardon (2007) article, Tables 1 and 3. The resulting European equation, estimated with a fixed effect regression model in the logits, for a cohort $c$ was $^{7}$ :

$$
\begin{aligned}
\operatorname{logit}\left(M_{\text {final }}^{c}\right)= & -0.426+3.953 \times M_{27}^{c} \\
& (0.69) \quad(0.97) \quad R^{2}=0.55
\end{aligned}
$$

Figure 3 shows the box plots ${ }^{8}$ for complete $G$ and $M$ in the 16 Latin American countries and in each of the four census waves, plus our prediction for the wave of 2010 (two scenarios for $M$ ). These are cohort estimates of quasi-complete $G$ and $M$, which will be observed in the census wave of 2010 for the 1970 cohorts. The figure also includes boxes of $G$ and $M$ for 22 European countries, with available estimates for cohorts born around 1970. It also shows the $M$ box in the hypothetical scenario that the 1975 cohort would complete $M$ with high rates of late motherhood, like in Europe. Overall, this figure confirms the precipitous decline in $G$ from cohorts born around 1930 (median of 5.7 births) to those born around 1960 (median of 2.6 births). This decline has somehow stalled for the cohorts born about 1970 (median 2.3 births) at a level well above the European median of about one birth per mother in the 1970 cohorts.

For the complete $M$ proportion -the main focus in this article-no clear trend can be seen when we move from the 1935 cohorts to the 1965 cohorts. The median $M$ hovers above 90\% motherhood, although in the 1965 cohorts there are signs that a decline has started. In contrast, the cohorts born by 1975 seem to be heading towards lower $M$ (median of 86\%), close to the $M$ level in the European cohorts of 1970 (median of 83\%). However, as indicated by the dashed box in the figure, if the 1975 cohorts have been simply delaying the onset of childbearing, and can be expected to have their first birth in their thirties, as in Europe, complete- $M$ (median of 91\%) will change little, and will stay above $90 \%$ median value. In this scenario, the only change will therefore be in the age at first birth. Reality may follow a path between these two scenarios, with a median $M$ between $86 \%$ and $91 \%$. Colombia is an extreme case, showing large differences between the two scenarios. Only $70 \%$ of women aged $25-29$ were mothers in the 2005 census (our 1975 birth cohort), compared to 82\% of the 1965 cohort in the

\footnotetext{
${ }^{7}$ Since the R-squared of 0.55 in the prediction equation is less than optimal for forecasting purposes, we consider this as just an alternative scenario.

${ }^{8}$ The line in the middle of the box indicates the median value of the distribution; the extremes of the box indicate the 25 and 75 percentiles.
} 
Figure 3: Trend in the approximately final $G$ and $M$ in five cohorts of 16 Latin American countries and in the 1970 cohort of 22 European countries

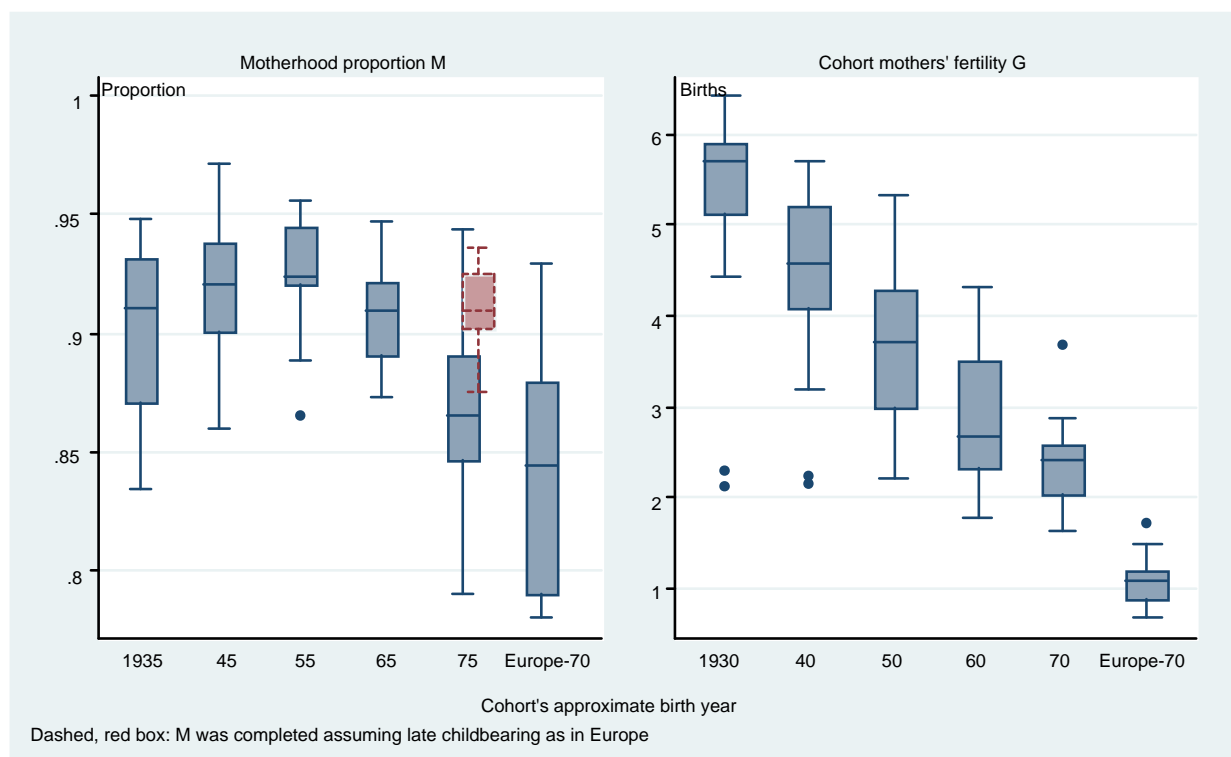

1993 census. Our estimates of the completed $M$ for the 1975 cohort range from 77\%, if we assume the continuation of the 1965 cohort first birth rates, to $90 \%$, if we assume the adoption of first birth patterns similar to those of Europe.

To what extent are $M$ and $G$ related to each other? Is fertility of second and higher order births influenced by the rate of entrance into motherhood? Lower $M$ usually means later age at first birth and a reduced exposure time for having second and higher order births. This exposure effect would be strong in a natural fertility setting. But even under perfectly controlled fertility conditions, later may mean fewer births, particularly for the tail of the age distribution of women who start childbearing by age 40 . However, if a lower $M$ comes from a retreat from reproduction by large numbers of couples, further fertility of those who choose to have children may or may not be lower than in the previous situation, in which women with low fertility desires were part of the pool of mothers. If there is a general reduction in fertility preferences, a reduced $M$ will go hand-in-hand with a reduced $G$. If, however, in some societies there is a divide between couples who opt out of parenthood and couples more oriented towards family and children, we will not observe an association between $G$ and $M$, or the association may even be inverse. 
Rosero-Bixby et al.: Is Latin America starting to retreat from early and universal childbearing?

Figure 4 shows the cross-sectional associations between the national levels of $M$ and $G$ in five successive Latin American cohorts and a recent European cohort. It is clear from the figure that the association between these two fertility components has changed over time. If we exclude the outliers Argentina and Uruguay from cohorts born in the 1930s and 1940s, there is almost no association between $G$ and $M$ in these cohorts. A positive and clear association takes shape in more recent generations of women, particularly in the 1950s and 1960s cohorts. However, the association weakens in the 1970s cohorts ${ }^{9}$. Moreover, an inverse relationship can be observed in the 1970s European cohorts: in societies with a lower proportion of women who are mothers, the fertility of mothers tends to be higher. This inverse association seems peculiar at first. However, it may simply mean that when $M$ falls below a certain threshold, those women with lower fertility preferences are removed from the pool of mothers; that is, women who would have one child at most may be the ones who opt out of motherhood, leaving a self-selected group of women with higher fertility preferences in the pool of mothers, which, consequently, results in a higher $G$-rate.

What factors increase the likelihood of being childless (even if only temporarily) among young adults? Do these factors act differently than in earlier cohorts? Table 1 shows the results of a multivariate analysis on the probability of being childless among the 9,000 respondents of the LAPOP surveys of the Americas Barometer 2006. We present separate models for all women aged 20-49, and for each of the 10-year age brackets; i.e., for 10-year cohorts with central birth years at 1980, 1970, and 1960. All models include controls for age and country.

As expected, there is a clear and positive effect of education on childlessness (Castro-Martín and Juarez 1995). College-educated women are about four times more likely to be childless than women with no education or incomplete elementary school. This effect does not differ much in young and old cohorts. Working women, in turn, are twice as likely as housewives to be childless, but this effect is present and significant only in younger cohorts. However, the direction of causality in this relationship cannot be determined from the available data; i.e., we cannot tell whether women are childless because they are in the labor force, or whether they are more likely to be in the labor force because they are childless. Women who get the news mostly from newspapers are more likely to be childless, whereas the opposite occurs among women who get the news mostly from TV. The model does not show clear effects on childlessness based on residence in urban or metropolitan areas once we control for education, or from the indicators of social capital in the community (measured by the trust scale). Contrary to

\footnotetext{
${ }^{9}$ The scatter graph for the 1970 cohort $M$ that was predicted with the European relationship differs little from the one shown in Figure 4. The correlation coefficient is 0.70, compared to 0.71 in Figure 4.
} 
Figure 4: Cross-sectional relationships between G and M. Latin American (LA) countries cohorts 1930-1970 and Europe cohort 1970
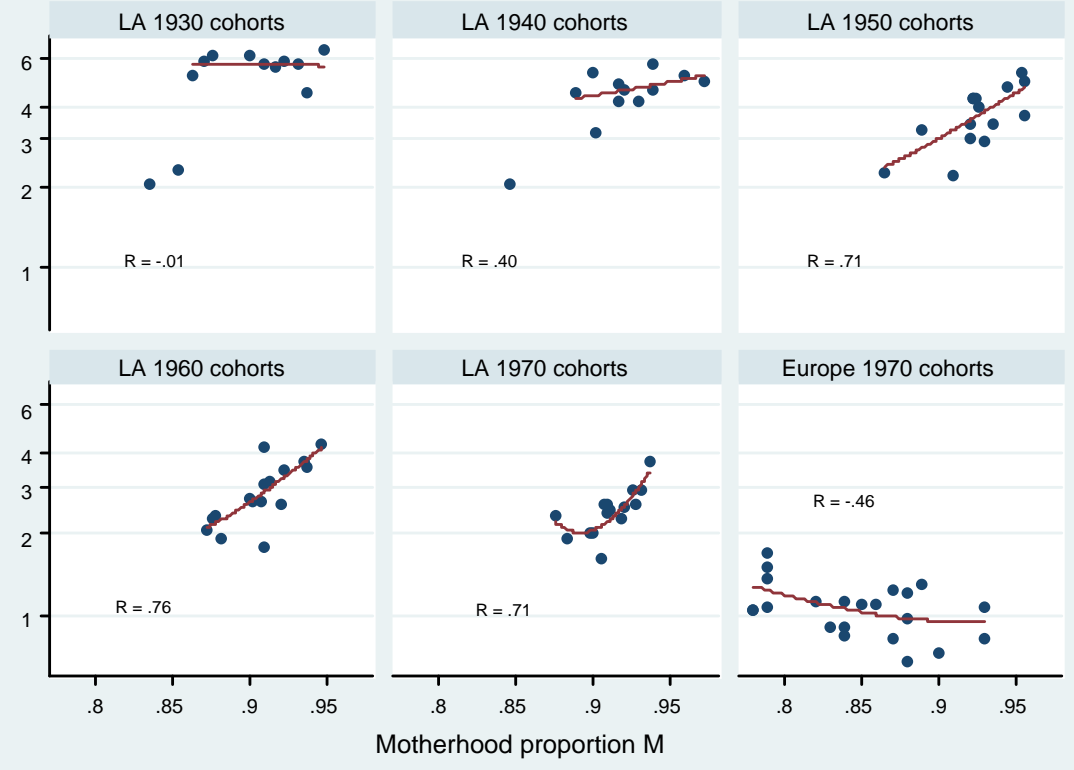

Note: the two outliers in 1930 are Argentina and Uruguay; the outlier in 1940 is Argentina.

$R$ is the correlation coefficient (excluding the outliers)

the popular view that religious affiliation and church attendance have a strong influence on women's fertility behavior in Latin America, our data show no effect of these factors on childlessness. 
Rosero-Bixby et al.: Is Latin America starting to retreat from early and universal childbearing?

Table 1: Logistic regressions on the probability of being childless. LAPOP-2006 surveys, in 14 Latin American countries

\begin{tabular}{|c|c|c|c|c|c|c|c|c|}
\hline \multirow[b]{3}{*}{ Explanatory variables } & \multicolumn{2}{|c|}{ Total } & \multicolumn{2}{|c|}{ Age 20-29 } & \multicolumn{2}{|c|}{ Age 30-39 } & \multicolumn{2}{|c|}{ Age $40-49$} \\
\hline & Odds & & Odds & & Odds & & Odds & \\
\hline & Ratio & $P>|z|$ & Ratio & $P>|z|$ & Ratio & $P>|z|$ & Ratio & $P>|z|$ \\
\hline$(\mathrm{N})$ & $(8,925)$ & & $(3,717)$ & & $(2,802)$ & & $(2,406)$ & \\
\hline \multicolumn{9}{|l|}{ Marital status } \\
\hline With no couple & 1 & Ref. & 1.00 & Ref. & 1 & Ref. & 1 & Ref. \\
\hline Common law union & 0.09 & 0.00 & 0.08 & 0.00 & 0.10 & 0.00 & 0.16 & 0.00 \\
\hline Married & 0.07 & 0.00 & 0.09 & 0.00 & 0.05 & 0.00 & 0.11 & 0.00 \\
\hline \multicolumn{9}{|l|}{ Place of residence } \\
\hline Metropolitan & 0.89 & 0.29 & 0.77 & 0.07 & 1.15 & 0.58 & 1.22 & 0.50 \\
\hline Other Urban & 0.80 & 0.07 & 0.77 & 0.09 & 1.13 & 0.66 & 0.59 & 0.16 \\
\hline Rural & 1 & Ref. & 1.00 & Ref. & 1 & Ref. & 1 & Ref. \\
\hline \multicolumn{9}{|l|}{ Education } \\
\hline Incomplete elementary & 1 & Ref. & 1.00 & Ref. & 1 & Ref. & 1 & Ref. \\
\hline Completed elementary & 1.44 & 0.04 & 1.24 & 0.36 & 1.66 & 0.17 & 1.82 & 0.12 \\
\hline High school & 1.70 & 0.00 & 1.70 & 0.01 & 1.58 & 0.15 & 1.78 & 0.10 \\
\hline College & 3.72 & 0.00 & 4.06 & 0.00 & 3.61 & 0.00 & 5.19 & 0.00 \\
\hline \multicolumn{9}{|l|}{ Occupation } \\
\hline Housewife & 1 & Ref. & 1.00 & Ref. & 1 & Ref. & 1 & Ref. \\
\hline White-collar / student & 2.03 & 0.00 & 2.69 & 0.00 & 1.26 & 0.32 & 0.94 & 0.83 \\
\hline Blue-collar & 1.48 & 0.00 & 1.71 & 0.00 & 1.11 & 0.63 & 1.37 & 0.21 \\
\hline \multicolumn{9}{|l|}{ Religion } \\
\hline Catholic & 1 & Ref. & 1.00 & Ref. & 1 & Ref. & 1 & Ref. \\
\hline No Catholic & 1.08 & 0.45 & 1.21 & 0.13 & 0.74 & 0.20 & 1.17 & 0.55 \\
\hline No religion & 1.03 & 0.83 & 1.26 & 0.25 & 0.79 & 0.51 & 0.55 & 0.34 \\
\hline \multicolumn{9}{|l|}{ Church attendance } \\
\hline Weekly vs. less than weekly & 1.09 & 0.30 & 1.11 & 0.33 & 0.82 & 0.28 & 1.28 & 0.27 \\
\hline
\end{tabular}


Table 1: (Continued)

\begin{tabular}{|c|c|c|c|c|c|c|c|c|}
\hline \multirow[b]{3}{*}{ Explanatory variables } & \multicolumn{2}{|c|}{ Total } & \multicolumn{2}{|c|}{ Age $20-29$} & \multicolumn{2}{|c|}{ Age 30-39 } & \multicolumn{2}{|c|}{ Age $40-49$} \\
\hline & \multicolumn{2}{|c|}{ Odds } & \multicolumn{2}{|c|}{ Odds } & \multicolumn{2}{|c|}{ Odds } & \multicolumn{2}{|c|}{ Odds } \\
\hline & Ratio & $P>|z|$ & Ratio & $P>|z|$ & Ratio & $P>|z|$ & Ratio & $P>|z|$ \\
\hline Trust scale (0 - 1) & 1.08 & 0.55 & 1.07 & 0.70 & 0.84 & 0.53 & 1.25 & 0.54 \\
\hline TV informed scale $(0-1)$ & 0.62 & 0.00 & 0.54 & 0.00 & 0.66 & 0.18 & 0.77 & 0.48 \\
\hline Paper informed scale $(0-1)$ & 1.42 & 0.01 & 1.37 & 0.06 & 1.47 & 0.16 & 1.43 & 0.29 \\
\hline Satisfied with life scale $(0-1)$ & 2.26 & 0.00 & 2.23 & 0.00 & 1.63 & 0.17 & 0.71 & 0.44 \\
\hline Wealth scale $(0-1)$ & 2.85 & 0.00 & 2.97 & 0.00 & 4.33 & 0.00 & 0.31 & 0.05 \\
\hline \multicolumn{9}{|l|}{ Age groups and interactions } \\
\hline $20-29$ & 1 & Ref. & & & & & & \\
\hline $30-39$ & 1.22 & 0.62 & & & & & & \\
\hline $40-49$ & 9.43 & 0.00 & & & & & & \\
\hline \multicolumn{9}{|l|}{ Life satisfaction and } \\
\hline Age $30-39$ & 0.58 & 0.17 & & & & & & \\
\hline Age $40-49$ & 0.35 & 0.02 & & & & & & \\
\hline \multicolumn{9}{|l|}{ Wealth and } \\
\hline Age $30-39$ & 1.23 & 0.61 & & & & & & \\
\hline Age $40-49$ & 0.24 & 0.00 & & & & & & \\
\hline
\end{tabular}

Note: All regressions included controls for age (continuous) and country (13 dummy variables).

Source: LAPOP surveys project data online at http://encuestas.ccp.ucr.ac.cr/Lapop.html

The effects on childlessness of the scales of wealth and satisfaction with life deserve a closer look. The odds ratios show that the direction of these effects reversed in younger cohorts. This change of direction is statistically significant, as shown by the interaction effects included in the all ages model. The findings indicate that women who are wealthier or more satisfied with life are less likely to be childless in older cohorts, and are more likely to be childless in younger cohorts. Among younger women, going from zero to one on the wealth scale increases the odds of being childless almost threefold, whereas among older cohorts, it reduces the odds to about one-third. Regarding satisfaction with life, going from zero to one on the scale more than doubles the odds of being childless among younger women, and reduces the odds by $30 \%$ among older women. If these were truly cohort effects, as opposed to age effects, they would stand for a dramatic generational change: childlessness now seems linked to happiness and wealth, in contrast to the trends seen only a generation ago, in which childless women reported being less happy and less wealthy. Nevertheless, we should 
interpret these cross-sectional relationships with caution because of possible reverse causality and the confounding effects of age and cohort.

Figure 5 re-examines the robust effect of education on the motherhood proportion $M$ among women aged 25-29 using data from the two most recent censuses in nine Latin American countries. The educational gap in $M$ is large and persistent over time. Having a college education seems particularly important for two reasons: (1) the $M$ gap for college is larger than for lower educational levels, and (2) college-educated women are the only group with a clear reduction in $M$ over time in the nine countries. In Costa Rica, for example, only $43 \%$ of women aged 25-29 who attended college are mothers in the 2000 census, compared to $76 \%$ and $84 \%$ of women with high school and primary education, respectively. Moreover, in this country, the proportion of mothers among college-educated women fell 15 percentage points from the 1984 to the 2000 census, whereas the $M$ proportion remained fairly stable in the other two educational groups. Among college-educated women, $M$ dropped 14 percentage points in Panama, 11 points in Mexico, nine points in Colombia, seven points in Argentina and Brazil, five points in Nicaragua, and one point in Venezuela.

Therefore, the fall in the $M$ proportion among women with college education seems to be a key factor in understanding the emerging retreat from childbearing in Latin America observed in recent years. Another key factor in understanding this trend is the growing numbers of women receiving a college education. In the age bracket 2529, the percentage of women who attended college increased in the last two censuses by 18 points in Chile; 15 points in Colombia; 10 points in Venezuela; eight points in Argentina, Costa Rica, and Nicaragua; but only one to three points in Panama, Brazil, and Mexico (Table 2). In the 2000 wave of censuses, college-educated women in this age bracket range from low levels of $11 \%$ in Brazil and 14\% in Mexico and Nicaragua, to highs of 32\% in Argentina and Chile, and 27\% in Colombia and Venezuela.

In a quick exercise to estimate the impact of the changing educational composition on $M$, we computed for the nine countries in Figure 5 a hypothetical $M$ for the 2000 census wave, assuming that the educational composition was that of the 1990 census wave. The result of this exercise is presented in Table 2, and suggests that educational improvement might be responsible for all of the observed national change in $M$ in Argentina, Brazil, Chile, and Venezuela; and for about half of the $M$ change in Colombia, Costa Rica, Mexico, and Nicaragua. In other words, about half the decline in $M$ in these four countries (and $80 \%$ in Panama) comes from $M$ reductions within educational groups, mostly among women with a college education, meaning that factors other than the improvement in women's education may also need to be considered if we are to fully understand the recent decline in $M$. 
Figure 5: Motherhood proportion $M$ at age 25-29 by education in the two most recent censuses, selected countries

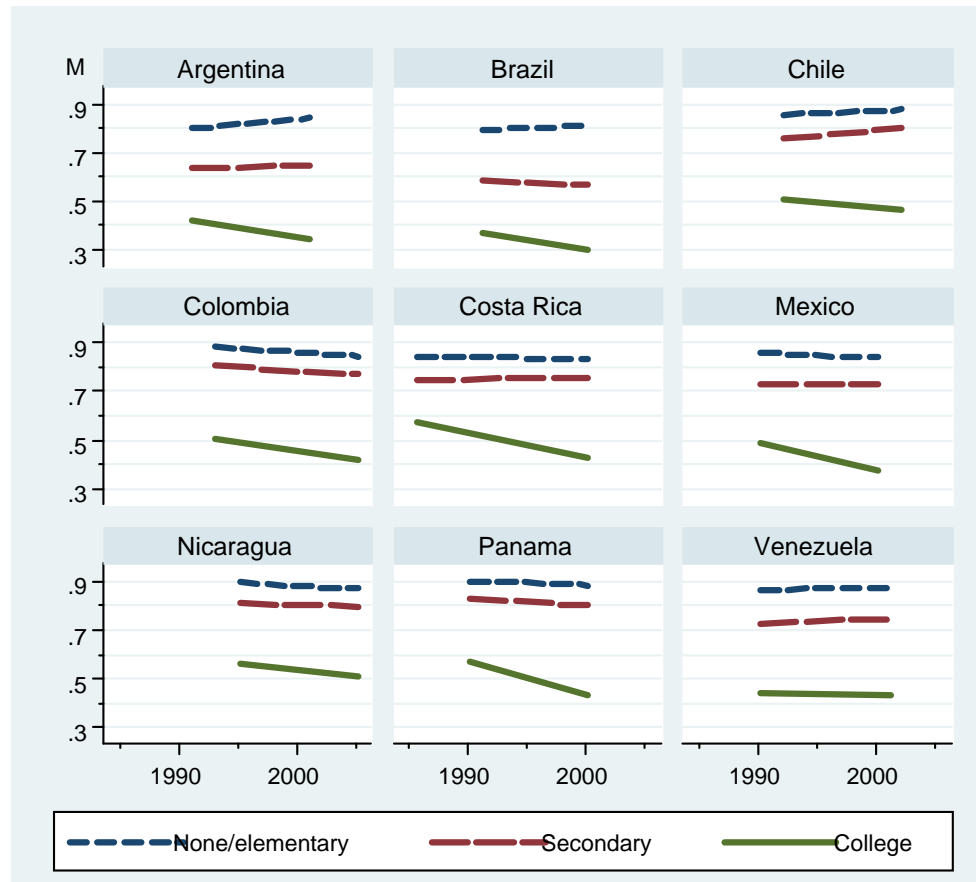

If the recent enhancement in women's education explains a significant portion of the recent drop in the percentage of women who become mothers, why then did past educational improvements not produce a similar result? The answer might be that educational improvements in the past occurred mostly at the primary and secondary levels and, as Figure 5 suggests, in most countries there are only small differences in $M$ at these lower educational levels. It is college education that seems to make a difference in the timing and level of transition to motherhood. 
Rosero-Bixby et al.: Is Latin America starting to retreat from early and universal childbearing?

Table 2: $\quad$ Educational composition and $M$ proportion in women aged 25-29 in the two most recent censuses

\begin{tabular}{|c|c|c|c|c|c|c|c|c|}
\hline \multirow[b]{2}{*}{$\begin{array}{l}\text { Country } \\
\text { year }\end{array}$} & \multicolumn{4}{|c|}{ Educational composition of women } & \multicolumn{4}{|c|}{$M$ proportion } \\
\hline & $\begin{array}{c}\text { Nonel } \\
\text { elementary }\end{array}$ & $\begin{array}{c}\text { High } \\
\text { school }\end{array}$ & College & Total & $\begin{array}{c}\text { None I } \\
\text { elementary }\end{array}$ & $\begin{array}{c}\text { High } \\
\text { school }\end{array}$ & College & Total \\
\hline \multicolumn{9}{|l|}{ Argentina } \\
\hline 1991 & 50 & 25 & 25 & 100 & 0.81 & 0.65 & 0.43 & 0.67 \\
\hline 2001 & 38 & 30 & 32 & 100 & 0.85 & 0.65 & 0.36 & 0.63 \\
\hline \multicolumn{5}{|c|}{ Percent $M$-change explained by education } & & & & 100 \\
\hline
\end{tabular}

Brazil

$\begin{array}{lllllllll}1991 & 67 & 23 & 10 & 100 & 0.80 & 0.59 & 0.38 & 0.71 \\ 2000 & 60 & 29 & 11 & 100 & 0.82 & 0.58 & 0.31 & 0.69\end{array}$

$\begin{array}{ll}\text { Percent } M \text {-change explained by education } & 100\end{array}$

Chile

$\begin{array}{lllllllll}1992 & 37 & 48 & 15 & 100 & 0.86 & 0.77 & 0.51 & 0.76 \\ 2002 & 23 & 45 & 32 & 100 & 0.88 & 0.81 & 0.47 & 0.72\end{array}$

$\begin{array}{ll}\text { Percent } M \text {-change explained by education } & 100\end{array}$

Colombia

$\begin{array}{lllllllll}1993 & 56 & 32 & 12 & 100 & 0.89 & 0.81 & 0.51 & 0.82\end{array}$

$\begin{array}{lllllllll}2005 & 26 & 47 & 27 & 100 & 0.85 & 0.78 & 0.43 & 0.70\end{array}$

Percent $M$-change explained by education $\quad 63$

Costa Rica

$\begin{array}{lllllllll}1984 & 52 & 34 & 14 & 100 & 0.85 & 0.76 & 0.58 & 0.78 \\ 2000 & 48 & 31 & 21 & 100 & 0.84 & 0.76 & 0.43 & 0.73\end{array}$

Percent $M$-change explained by education $\quad \mathbf{5 1}$ Mexico

$\begin{array}{lllllllll}1990 & 56 & 32 & 12 & 100 & 0.87 & 0.74 & 0.50 & 0.78 \\ 2000 & 39 & 47 & 14 & 100 & 0.85 & 0.74 & 0.39 & 0.73\end{array}$

Percent $M$-change explained by education $\quad 51$ Nicaragua

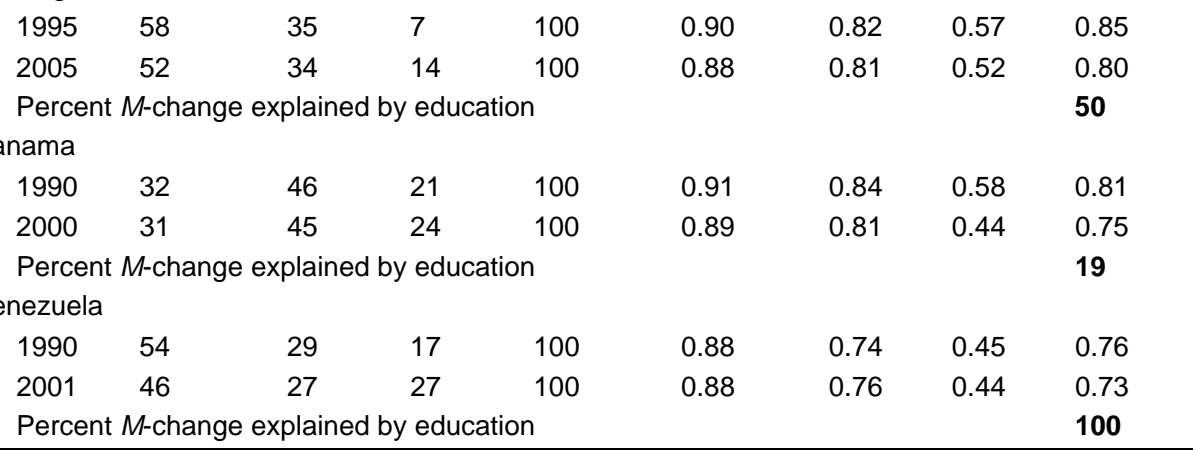




\section{Discussion}

This article documents the growing proportion of Latin American women in their twenties and early thirties who have not made the transition to motherhood. This emerging trend certainly means a shift in the region toward a later onset of childbearing, but it could also mean that some women are choosing to forgo having children. Until recently, one of the singular demographic features of the region was that rapid and sustained fertility decline occurred without a concomitant change in the timing of union formation, or in the onset of childbearing. Early and almost universal childbearing persisted in spite of radical changes in the demographic, economic, social, and political spheres. There is, however, recent evidence that young cohorts are departing from this traditional pattern, and that Latin American women are waiting longer to become mothers. Although age at first birth had remained fairly stable since the 1970s, the data presented from the 2000 wave of censuses reveals that the proportion of women aged 25 to 29 who are still childless increased in almost all the countries analyzed. Data from vital statistics for Chile and Costa Rica also corroborate this new trend towards later motherhood.

The emerging trend in postponement of childbearing raises the question of whether this development will lead to an increase in the region in permanent childlessness voluntarily chosen or because of age-related infecundity- as has been the case in European countries countries (González and Jurado-Guerrero 2006, Tanturri and Mencarini 2008). Our estimates of the proportion of women born in 1975 who will eventually become mothers are not conclusive: an important drop could take place if these women follow the traditional pattern of low rates of transition to motherhood beyond age 30, but no significant drop would take place if there is a recovery with high rates of transition to motherhood among women in their thirties, as in many European countries. Nevertheless, the increase in childlessness in the customarily prime ages of reproduction (25 to 29), even if transitory, deserves attention. It signals an important change in societies where the social imperative of motherhood has been traditionally strong, and where women who wished to postpone their first birth or remain childless were commonly stigmatized as selfish. Latin American cultural constructions of femininity have been strongly influenced by women's symbolic and social roles as mothers (Jelin 1990). Nowadays, motherhood continues to play a central role in women's lives, but there has been an expansion of women's non-familial identities and roles, possibly rendering the deferment of childbearing an acceptable option.

Beyond the normative context, economic constraints and competing opportunities are also likely to play a major role in shaping decisions and behaviors regarding childbearing. In the face of enhanced female labor market prospects, increased economic insecurity, or rising conjugal instability, delayed childbearing might become 
an increasingly common strategy for dealing with uncertainty, as has occurred in Europe (Billari, Liefbroer, and Philipov 2006). The impact of economic instability on family formation, as well as variations in the perception, tolerance, and reactions to economic insecurity across educational strata and social contexts, deserve further attention (Bernardi, Klärner, and Lippe 2008).

It is not evident whether these changes should be interpreted under the lens of the second demographic transition (van de Kaa 1987). The validity of that framework to explain recent family changes in Latin America is at the center of contemporary debates (Quilodrán 1999, García and Rojas 2001). Divergent views persist on whether to interpret recent family dynamics as an outcome of diffusion processes of new cultural patterns, or as a reflection of the lack of social cohesion within excluded sectors (Arriagada 2002). Some demographic features of Latin American societies, such as the high prevalence of consensual unions or frequent union disruption, can be linked to either modernity or tradition, depending on the social group we focus on (Castro-Martín 2002). The delayed onset of childbearing can, however, be unequivocally labelled as innovative behavior. Furthermore, our education-specific trend analysis has shown that it is precisely the highly educated strata who have taken the lead in this behavioral change. In fact, a great deal of the overall increase in childlessness among young adults is due to the upgraded educational composition of the population. We argue that major educational improvements in the past did not have a comparable impact on the timing of motherhood because they were focused on the universalization of primary education. In contrast, the more recent expansion of secondary education, and of college education in particular, is becoming a powerful force in restructuring the transition to adulthood and, consequently, the process of family formation (Grant and Furstenberg 2007). Yet in some countries, there is more to delayed fertility than a shift in the educational distribution of the population. In Nicaragua, Mexico, Costa Rica, Colombia, and Panama, for example, we have documented significant changes in the proportion of mothers within educational strata or, more precisely, within the college-educated group.

The multivariate analysis of a recent survey across 14 Latin American countries also reveals that high educational attainment is the most influential factor predicting childlessness among women of all ages. Hence, although our data do not allow us to link the recent increase in childlessness at young adulthood to "post-materialist" values (Lesthaeghe and Moors 1995, van de Kaa 2001), such as the search for individual autonomy or gender equality, the fact that highly educated women are the main protagonists of the observed trend points towards a change in values and competing life priorities that discourage early childbearing.

It is not certain whether a delayed childbearing pattern will spread across the entire population. Latin America continues to display some of the highest levels of inequality in the world (Portes and Hoffman 2003), and the social processes that bring about 
family change in different social strata remain quite heterogeneous. Furthermore, the large socioeconomic divide that characterizes many Latin American societies may act as an insurmountable barrier against the diffusion of social values regarding family, parenthood, and the optimal calendar for adulthood transitions. Yet it seems clear that the social imperative of early motherhood that prevailed during most of the 20th century has started to weaken, and that we are witnessing an increasing destandardization of the life course.

There are multiple areas in which this research could be expanded in the future. One logical extension is to test cohort differentials regarding the timing and the determinants of the transition to motherhood within a life course framework, using retrospective birth histories from survey data. The problem is that, since childbearing postponement is an emerging trend, it might be visible only in recent data, and not many Latin American countries have conducted demographic surveys in recent years. An additional direction for analysis would be to examine the prevalence and correlates of childlessness among men, since socio-cultural expectations and competing opportunities shaping attitudes, decisions, and fertility behavior are fundamentally gendered.

\section{Acknowledgements}

The Wellcome Trust Foundation (grant WT072406), the Spanish Ministry of Education and Science (grant SEJ2006-03485) and an UCR-CSIC scientific cooperation agreement supported in part this research. 


\section{References}

Adsera, A. and Menéndez, A. (2006). Fertility changes in Latin America in the context of economic and political uncertainty. Paper presented at the XX Annual Conference of the European Society for Population Economics, Verona, June 22-23 2006.

Arriagada, I. (2002). Changes and inequalities in Latin American families. CEPAL Review 77: 135-153.

Bernardi, L., Klärner, A., and Lippe, H. (2008). Job insecurity and the timing of parenthood: A comparison between Eastern and Western Germany. European Journal of Population 24(3): 287-313. doi:10.1007/s10680-007-9127-5.

Billari, F. C., Liefbroer, A. C., and Philipov, D. (2006). The postponement of childbearing in Europe: driving forces and implications. Vienna Yearbook of Population Research 2006: 1-17. doi:10.1553/populationyearbook2006s1.

Bongaarts, J. and Feeney, G. (1998). On the quantum and tempo of fertility. Population and Development Review 24(2): 271-291. doi:10.2307/2807974.

Castro Martin, T. (2002). Consensual unions in Latin America: persistence of a dual nuptiality system. Journal of Comparative Family Studies 33(1): 35-55.

Castro Martin, T. and Juárez, F. (1995). The impact of women's education on fertility in Latin America: searching for explanations. International Family Planning Perspectives 21(2): 52-57. doi:10.2307/2133523.

CCP [Centro Centroamericano de Población] (2008). Consulta a Censos y Grandes Bases de Datos Estadísticas [electronic resource]. San José, Costa Rica: University of Costa Rica. http://censos.ccp.ucr.ac.cr.

Coale, A. J. and Watkins, S. C. (1986). The decline of fertility in Europe. Princeton: Princeton University Press.

Council of Europe (2005). Recent demographic developments in Europe 2004. Strasbourg: Council of Europe Publishing

Crimmins, E. M., Easterlin, R. A., and Saito, Y. (1991). Preferences changes among American youth: family, work and goods. Population and Development Review 17: 115-133. doi:10.2307/1972355.

ECLAC (Economic Commission for Latin America and the Caribbean) (2007). Panorama social de Latinoamérica. Santiago, Chile: United Nations publication LC/G.2351-P/E. 
Frejka, T. and Sardon, J.-P. (2007). Cohort birth order, parity progression ratio and parity distribution trends in developed countries. Demographic Research 16(11): 315-374. doi:10.4054/DemRes.2007.16.11.

Fussell, E. (2005). Measuring the early adult life course in Mexico: An application of the entropy index. In: Macmillan, R. (ed.). The structure of the life course: Standardized? Individualized? Differentiated? (Advances in Life Course Research, Volume 9). Amsterdam: Elsevier: 91-122.

Fussell, E. and Palloni, A. (2004). Persistent marriage regimes in changing times. Journal of Marriage and the Family 66: 1201-1213. doi:10.1111/j.00222445.2004.00087.x.

García, B. and Rojas, O. (2001). Recent transformations in Latin American families: A sociodemographic perspective. Paper presented at the XXIV IUSSP General Population Conference, Salvador de Bahía, Brasil, August 18-24 2001.

González, M. J. and Jurado-Guerrero, T. (2006). Remaining childless in affluent economies: A comparison of France, West Germany, Italy and Spain, 19942001. European Journal of Population 22(4): 317-352. doi:10.1007/s10680006-9000-y.

Grant, M. J. and Furstenberg, F. F. (2007). Changes in the transition to adulthood in less developed countries. European Journal of Population 23: 415-428. doi:10.1007/s10680-007-9131-9.

Guzmán, J. M., Singh, S., Rodríguez, G., and Pantelides, E. A. (eds.) (1996). The fertility transition in Latin America. Oxford: Clarendon Press.

Heaton, T. B., Forste, R., and Otterstrom, S. M. (2002). Family transitions in Latin America: first intercourse, first union and first birth. International Journal of Population Geography 8: 1-15. doi:10.1002/ijpg.234.

Jelin, E. (ed.) (1990). Women and social change in Latin America. London: Zed Books and Geneva: UNRISD.

Jelin, E. and Díaz-Muñoz, A. R. (2003). Major trends affecting families: South America in perspective. Report prepared for United Nations Department of Economic and Social Affairs Division for Social Policy and Development Programme on the Family. Mimeo.

Kohler, H. P., Billari, F., and Ortega, J. A. (2002). The emergence of lowest-low fertility in Europe during the 1990s. Population and Development Review 28(4): 641-680. doi:10.1111/j.1728-4457.2002.00641.x. 
LAPOP [Latin American Public Opinion Project] (2008). LAPOP and AmericasBarometer [electronic resource]. Nashville: Vanderbilt University. http://www.vanderbilt.edu/lapop.

Lesthaeghe, R. and Moors, G. (1995). Living Arrangements and Parenthood: Do Values Matter? In De Moor, R. (ed.). Values in Western Societies. Tilburg: Tilburg University Press.

Mensch, B. S., Singh, S., and Casterline, J. B. (2005). Trends in the timing of first marriage among men and women in the developing world. In: Lloyd, C. L. et al. (eds.). The changing transitions to adulthood in developing countries: selected studies. Washington, D.C.: National Academies Press: 118-171.

Minnesota Population Center (2008). Integrated Public Use Microdata Series (IPUMS) - International: Version 4.0. [electronic resource]. Minneapolis: University of Minnesota. http://international.ipums.org

Population Reference Bureau (2007). 2007 World population data sheet. Washington DC: PRB publications.

Portes, A. and Hoffman, K. (2003). Latin American class structures: Their composition and change during the neoliberal era. Latin American Research Review 38: 4182. doi:10.1353/lar.2003.0011.

Potter, J. E., Schmertmann, C. P., and Cavenaghi, S. (2002). Fertility and development: evidence from Brazil. Demography 39(4):739-761. doi:10.1353/dem.2002.0039.

Quilodrán, J. (1999). L'union libre en Amérique Latine: aspects récents d'un phenomene seculaire. Cahiers Quebecois de Demographie 28(1-2): 53-80.

Rindfuss, R. R. and Bumpass, L. L. (1976). How old is too old? Age and the sociology of fertility. Family Planning Perspectives 8(5): 226-230. doi:10.2307/2134315.

Rosero-Bixby, L. (1996). Nuptiality trends and fertility transition in Latin America. In: Guzman, J. M., Singh, S., Rodriguez, G. and Pantelides, E. A. (eds.). The fertility transition in Latin America. Oxford: Oxford University Press: 135-150.

Rosero-Bixby, L. (2004). La fecundidad en áreas metropolitanas de América Latina: la fecundidad de reemplazo y más allá. Notas de Población 37(78): 35-63.

Rutstein, S. O. and Shah, I. H. (2004). Infecundity, infertility, and childlessness in developing countries. DHS Comparative Reports No. 9. Calverton, Maryland, USA: ORC Macro. 
Ryder, N. (1964). The process of demographic translation. Demography 1(1): 74-82. doi:10.2307/2060032.

Sardon, J.-P. (2006). Recent demographic trends in the developed countries. Population-E 61(3): 197-266.

Sobotka, T. (2004). Postponement of childbearing and low fertility in Europe. [PhD thesis.] University of Groningen, Amsterdam: Dutch University Press.

Tanturri, M. L. and Mencarini, L. (2008). Childless or childfree? Paths to voluntary childlessness in Italy. Population and Development Review 34(1): 51-77. doi:10.1111/j.1728-4457.2008.00205.x.

United Nations (2004). World fertility report 2003. New York: United Nations Population Division. Sales No. E.04.XIII.10.

United Nations (2007). World Population Prospects: The 2006 Revision Population Database [electronic resource]. http://esa.un.org/unpp/

Van de Kaa, D. J. (2001). Postmodern fertility preferences: From changing value orientation to new behavior. In: Bulatao, R. A. and Casterline, J. B. (eds.). Global fertility transition. Supplement to Population and Development Review 27: 290-331.

Van de Kaa, D. J. (1987). Europe’s second demographic transition. Population Bulletin 42: 3-57.

Westoff, C. F. and Bankole, A. (2002). Reproductive preferences in developing countries at the turn of the century. DHS comparative reports 2. Calverton, Maryland: ORC Macro. 
Rosero-Bixby et al.: Is Latin America starting to retreat from early and universal childbearing? 